Schwartz, S. \& Zagaria, R. (1951). In Toxicology of Uranium, p. 290. Ed. by Tannenbaum, A. New York: McGraw-Hill.

Schwartz, S., Zieve, L. \& Watson, C. J. (1951). J. Lab. clin. Med. 37, 843.

Vigliani, E. C. (1938). Arch. Sci. med. 65, 391.

Vigliani, E., Angeleri, C. \& Sano, M. (1938). Arch. Sci. med. 65, 423.
Vigliani, E. \& Libowitzky, H. (1937). Klin. Wschr. 36, 1243.

Watson, C. J. (1937). J. clin. Invest. 16, 383.

Watson, C. J., de Mello, R. P., Schwartz, S., Hawkinson, V. E. \& Bossenmaier, I. (1951). J. Lab. clin. Med. 37, 831 . Weatherall, M. (1948). Brit. J. Pharmacol. 3, 137.

Weatherall, M. \& Comfort, A. (1952). Nature, Lond., 169, 587.

\title{
The Preparation and Properties of $\beta$-Glucuronidase
}

\section{SPECIFICITY}

\author{
By G. A. LEVVY AND C. A. MARSH \\ Rowett Research Institute, Bucksburn, Aberdeenshire
}

(Received 2 June 1952)

Knowledge of the specificity of the enzyme $\beta$ glucuronidase present in animal tissues is far from complete. Masamune (1934) found that the enzyme would hydrolyse neither laevomenthyl $\alpha$-D-glucuronide nor a variety of $\alpha$ - and $\beta$-D-glucosides. Phenyl $\beta$-D-glucoside was slowly hydrolysed by Masamune's enzyme preparation, but Graham (1946) obtained no hydrolysis of this compound with highly purified ox-spleen $\beta$-glucuronidase. Karunairatnam (1950) found that phenyl $\beta$-D-glucoside was hydrolysed by mouse-liver homogenates, but that this property was lost in the early stages of purification of $\beta$-glucuronidase. Further information on the specificity of this enzyme, not recognized as such by the original authors, is provided by the work of Karunairatnam \& Levvy (1949) who, in their search for an efficient inhibitor, found that the rate of hydrolysis of phenyl $\beta$-D-glucuronide was unchanged in the presence of methyl $\alpha-D$-glucoside, methyl $\alpha$-D-mannoside, methyl $\beta$-D-glucoheptoside, methyl $\beta$-D-xyloside and methyl $\alpha$-D-galactoside. Had any of these compounds been substrates for the enzyme, a fall in the rate of liberation of phenol might have been expected.

Meyer, Linker \& Rapport (1951) found that $\beta$ glucuronidase hydrolysed the oligosaccharides which are the end products of the action of purified cesticular hyaluronidase on hyaluronic acid. In the absence of adequate knowledge of the specificity of $\beta$-glucuronidase, this finding could not be put forward as additional proof of the structure of hyaluronic acid. Implicit in the use of $\beta$-glucuronidase as a hydrolytic agent in the study of urinary steroids is the assumption that all the steroid set free in this way is initially conjugated with glucuronic acid. Further information on its specificity would increase the value of $\beta$-glucuronidase as a biochemical reagent. The difficulty of preparing suitable test compounds has been largely overcome by the development of a method for the oxidation of hexosides to hexuronides with gaseous oxygen in the presence of platinum catalyst (Marsh, 1952: cf. Fernandez-Garcia et al. 1950;Mehltretter, Alexander, Mellies \& Rist, 1951 ; Barker, Bourne \& Stacey, 1951). The opportunity has been taken to study the action of mouse-liver $\beta$-glucuronidase on $\alpha$ - and $\beta$-glucuronides, galacturonides and mannuronides, and on a variety of other compounds.

\section{EXPERIMENTAL}

Materials. The following compounds were synthesized by methods given in the literature and were converted into the corresponding conjugated hexuronic acids (Marsh, 1952): $(-)$-menthyl $\alpha$-D-glucopyranoside, methyl $\alpha$ - and $\beta$-Dgalactopyranosides, methyl $\alpha$ - and $\beta$-D-mannopyranosides, and $\beta$-D-glucopyranose-1-phosphate. Biosynthetic $\alpha$-Dglucopyranose-1-phosphate, presented by Dr R. J. Whelan, was likewise put through the oxidation procedure. It should be noted that $\beta$-D-glucuronic acid-1-phosphate has not been obtained pure. The glucuronic acid content of the specimen used here was $60 \%$ of theory for the tripotassium salt.

Methyl $\alpha$-D-glucopyranoside, phenyl $\beta$-D-glucopyranoside and ( -)-menthyl $\beta$-D-glucopyranoside were also prepared by standard methods. Methyl $\alpha$ - and $\beta$-D-glucofuranuronides were obtained in solution by treating the corre. sponding 3:6-lactones with dilute $\mathrm{NaOH}$. Methyl 4-methyl D-glucopyranuronide (mixture of $\alpha$ and $\beta$ forms) was obtained in solution from the amide by heating the latter with $\mathrm{NaOH}$ (Smith, 1951). This amide and the two glucofuranuronolactones were presented by Prof. F. Smith. Oxycellulose (polyanhydroglucuronic acid, Yackel \& Kenyon 1942) was presented by Imperial Chemical Industries, Ltd. (Explosives Group). It had a $\mathrm{COOH}$ content of $22 \%$ (theoretical value for polyanhydroglucuronic acid, $26 \%$ ), and was brought into solution by careful addition of dilute $\mathrm{NaOH}$, so that the $\mathrm{pH}$ never exceeded 7 .

The standard substrates, phenolphthalein, phenyl and ( -)-menthyl $\beta$-D-glucuronides, were biosynthetic.

Enzyme preparation. Unless stated to the contrary, the enzyme was prepared as follows. Mouse liver (1-2 g.) was homogenized in water and made up to a final volume of $9 \mathrm{ml}$. 
After adding $1 \mathrm{ml}$. M-acetate buffer, $\mathrm{pH} 5 \cdot 2$, the homogenate was incubated at $37^{\circ}$ for $30-60 \mathrm{~min}$., and centrifuged at $1500 \mathrm{~g}$ for $15 \mathrm{~min}$. The supernatant was decanted and to it was added an equal volume of saturated $\left(\mathrm{NH}_{4}\right)_{8} \mathrm{SO}_{4}$ solution. Precipitated protein was separated by centrifuging at $1500 \mathrm{~g}$ for 15 min., and taken up in a convenient volume of water.

For measuring the liberation of reducing sugar, and for certain other experiments, the preparation of the enzyme was modified as follows. The homogenate was incubated at $\mathrm{pH} 5.2$ for $4 \mathrm{hr}$, and the limits of precipitation with $\left(\mathrm{NH}_{4}\right)_{2} \mathrm{SO}_{4}$ were narrowed from 0 and $50 \%$ to 31 and $50 \%$ saturation. The final enzyme solution was dialysed for $48 \mathrm{hr}$. at $4^{\circ}$ before use.

Measurement of enzyme activity. Three methods were used. (1) The liberation of phenolphthalein from $0.00063 \mathrm{M}$ phenolphthalein glucuronide in acetate buffer, $\mathrm{pH} 5 \cdot 2$, in $1 \mathrm{hr}$. was measured by a modification (Levvy, 1952) of the method of Talalay, Fishman \& Huggins (1946). (2) The liberation of phenol from $0.015 \mathrm{~m}$-phenyl glucuronide in citrate buffer, $\mathrm{pH} 5 \cdot 2$, in $1 \mathrm{hr}$. was measured by the method of Kerr, Graham \& Levvy (1948), but using Ilford no. 608 red filter in the Spekker absorptiometer instead of the blue filter recommended in the original procedure. (3) Liberation of reducing sugar from various possible substrates during $2 \mathrm{hr}$. incubation at $37^{\circ}$ in acetate buffer, $\mathrm{pH} \mathrm{5.2,} \mathrm{was}$ measured by the method of Levvy (1946).

\section{RESULTS}

Effects on the hydrolysis of known substrates. All the compounds were examined for their effects on the hydrolysis of phenolphthalein glucuronide by glucuronidase, and the results are shown in Table 1. As shown by the action of phenyl $\beta$-glucuronide, the release of phenolphthalein should be slowed in the presence of an alternative substrate for the enzyme. This test for possible substrates has the advantage of being less dependent on the purity of the enzyme preparation than direct measurements of hydrolysis, but it does not discriminate between 'alternative substrate' and 'enzyme inhibitor'.

The galacturonides, mannuronides, glucofuranuronides and the 4-methylglucopyranuronide had no effects of any kind on the release of phenolphthalein and were ruled out as possible substrates, as were also the galactosides, mannosides, glucose1-phosphates and two of the glucosides.

Of the compounds which changed the rate of hydrolysis of phenolphthalein glucuronide, oxycellulose caused a fall which, on the basis of the glucurone content, was equal to that produced by glucuronic acid under identical conditions of test (see Levvy, 1952). On dialysis, the solutions of oxycellulose lost most of their depressant effect, but only $20 \%$ of the solid present in solution was found to be dialysable. The oxycellulose solutions were made up either to $\mathrm{pH} 5$, in which case they were buffered with acetate and dialysed against the same buffer, or to $\mathrm{pH} \mathrm{7,} \mathrm{in} \mathrm{which} \mathrm{case} \mathrm{the} \mathrm{unbuffered}$ solution was dialysed against water. Similar results were obtained in the two cases.

Table 1. Effects of possible alternative substrates on the hydrolysis of $0.00063 \mathrm{M}-$ phenolphthalein $\beta$-D-glucuronide by mouse-liver glucuronidase

\begin{tabular}{|c|c|c|}
\hline Compound & $\begin{array}{c}\text { Final } \\
\text { concentration } \\
(\mathbf{M})\end{array}$ & $\begin{array}{c}\text { Change in rate of } \\
\text { phenolphthalein } \\
\text { liberation } \\
\text { (\% control) }\end{array}$ \\
\hline ( - )-Menthyl $\alpha$-D-glucuronide & 0.01 & $+22^{*}$ \\
\hline ( -)-Menthyl $\beta$-D-glucuronide & 0.01 & $+5^{*}$ \\
\hline Phenyl $\beta$-D-glucuronide & 0.01 & -16 \\
\hline Methyl 4-methyl-D-glucuronide & 0.001 & 0 \\
\hline Methyl $\alpha$-D-glucofuranuronide & 0.0005 & $\mathbf{0}$ \\
\hline Methyl $\beta$-D-glucofuranuronide & 0.001 & 0 \\
\hline$\alpha$-Glucuronic acid-1-phosphate & 0.01 & $-48^{*}$ \\
\hline$\beta$-Glucuronic acid-1-phosphate & $0.001 \dagger$ & $-26^{*}$ \\
\hline Methyl $\alpha$-D-galacturonide & 0.01 & 0 \\
\hline Methyl $\beta$-D-galacturonide & 0.01 & 0 \\
\hline Methyl $\alpha$-D-mannuronide & 0.01 & $\mathbf{0}$ \\
\hline Methyl $\beta$-D-mannuronide & 0.01 & 0 \\
\hline$(-)$-Menthyl $\alpha$-D-glucoside & 0.001 & +4 \\
\hline Methyl $\alpha$-D-glucoside & 0.01 & 0 \\
\hline (-)-Menthyl $\beta$-D-glucoside & 0.0025 & +10 \\
\hline Phenyl $\beta$-D-glucoside & 0.01 & 0 \\
\hline$\alpha$-Glucose-1-phosphate & 0.01 & $\mathbf{0}$ \\
\hline$\beta$-Glucose-1-phosphate & 0.01 & $\mathbf{0}$ \\
\hline Methyl $\alpha$-D-galactoside & 0.01 & $\mathbf{0}$ \\
\hline Methyl $\beta$-D-galactoside & 0.01 & 0 \\
\hline Methyl $\alpha$-D-mannoside & 0.01 & $\mathbf{0}$ \\
\hline Methyl $\beta$-D-mannoside & $0 \cdot 01$ & $\mathbf{0}$ \\
\hline Oxycellulose (freshly prepared solution) & $0.01 \ddagger$ & -49 \\
\hline Oxycellulose (solution dialysed for $48 \mathrm{hr}$.) & $0.01 f$ & -6 \\
\hline Oxycellulose ( $48 \mathrm{hr}$. old solution) & $0.01 \ddagger$ & -42 \\
\hline
\end{tabular}

* Enzyme precipitated between 31 and $50 \%$ saturation with ammonium sulphate and final solution dialysed.

$\dagger$ Calculated on glucuronic acid content.

$\ddagger$ Calculated as glucurone (mol.wt. 176) before dialysis. 
The depressant effects of the two glucuronic acid1-phosphates on the hydrolysis of phenolphthalein glucuronide were consistent with the possibility that these compounds were substrates for the enzyme, but a number of other possibilities are considered later.

Activation of the hydrolysis of phenolphthalein glucuronide was observed in every experiment with menthyl $\alpha$-glucuronide, varying somewhat in degree with different enzyme preparations. Activation was obtained with both menthyl glucosides and with menthyl $\beta$-glucuronide. With the $\beta$-glucuronide, activation of the enzyme apparently overcame the expected effect of substrate competition on the rate of liberation of phenolphthalein. Control experiments showed that neither of the menthyl glucuronides catalysed the decomposition of phenolphthalein glucuronide in absence of enzyme. Activation of the enzyme by menthol derivatives did not appear to be a surface effect since the surfaceactive agent, Triton $\mathrm{X}-100$, did not activate the preparations used in the present experiments (Walker \& Levvy, 1951). Mouse-liver glucuronidase can be separated into two fractions with $\mathrm{pH}$ optima at 4.5 and 5.2 respectively (Kerr, Campbell \& Levvy, 1949). The activity of the mixture at a given $\mathrm{pH}$ is the sum of the activities of the two fractions at that $\mathrm{pH}$. With a given enzyme preparation, activation by menthyl $\alpha$-glucuronide was as great at $\mathrm{pH} 4.5$ as at $5 \cdot 2$, which appeared to exclude the possibility of a change in the pH-activity curve.

Release of phenol from phenyl $\beta$-glucuronide was likewise accelerated by menthol derivatives, as shown in Table 2. On increasing the concentration of menthyl $\beta$-glucuronide, however, the effect of substrate competition became obvious. The affinities of phenyl and laevomenthyl $\beta$-glucuronides for the active enzyme centre, it should be noted, are similar, whilst that of phenolphthalein glucuronide is much greater (Karunairatnam \& Levvy, 1949).

Table 2. Effects of menthol derivatives on the hydrolysis of 0.015M-phenyl $\beta$-D-glucuronide by mouseliver glucuronidase

$\begin{array}{cc}\begin{array}{c}\text { Final } \\ \text { concentration } \\ (\mathbf{M})\end{array} & \begin{array}{c}\text { Change in } \\ \text { rate of } \\ \text { phenol } \\ \text { liberation } \\ (\%) \text { control })\end{array} \\ 0.005 & +19 \\ 0.01 & -20 \\ 0.001 & +3 \\ 0.0005 & +6\end{array}$

The liberation of reducing sugar. Measurements were made of the liberation of reducing sugar from menthyl $\alpha$-glucuronide and from $\alpha$ - and $\beta$-glucuronic acid-1-phosphate. For purposes of comparison, hydrolysis of menthyl $\beta$-glucuronide by the various enzyme preparations was also followed. Results of representative experiments are shown in Table 3. Menthyl $\alpha$-glucuronide was neither a substrate for the enzyme, nor did it have any significant effect on the rate of hydrolysis of the $\beta$-anomer. Activation of the enzyme was presumably already at a maximum in the presence of the latter alone.

Neither $\alpha$ - nor $\beta$-glucuronic acid-1-phosphate yielded any reducing sugar after $2 \mathrm{hr}$. incubation at pH 5.2 in absence of enzyme, but both were hydrolysed in its presence. The glucuronic acid formed was insufficient to have accounted for the effects of the phosphates on the hydrolysis of phenolphthalein glucuronide (Table 1). Hydrolysis of the phosphates could have been due to $\beta$-glucuronidase or to a phosphatase in the preparation. Discrimination between these possibilities was made by the use of

\section{Table 3. Liberation of reducing sugar from various possible substrates by mouse-liver glucuronidase}

(Enzyme precipitated between 31 and 50\% saturation with ammonium sulphate and final solution dialysed. Results expressed as glucuronic acid liberated in $0.8 \mathrm{ml}$. incubation mixture.)

Exp.

1

2

3
Substrate

0.01 M-Menthyl $\beta$-glucuronide 0.005 M-Menthyl $\alpha$-glucuronide 0.01 M-Menthyl $\beta$-glucuronide

$0.01 \mathrm{M}$-Menthyl $\beta$-glucuronide $0.01 \mathrm{M}$-Menthyl $\beta$-glucuronide 0.01 M- $\alpha$-Glucuronic acid-1-phosphate 0.01 M- $\alpha$-Glucuronic acid-1-phosphate 0.01 M- $\alpha$-Glucuronic acid-1-phosphate

$0.01 \mathrm{M}$-Menthyl $\beta$-glucuronide 0.01 M-Menthyl $\beta$-glucuronide $0.002 \mathrm{M}-\beta$-Glucuronic acid-1-phosphate* $0.002 \mathrm{~m}-\beta$-Glucuronic acid-1-phosphate* $0.002 \mathrm{M}-\beta$-Glucuronic acid-1-phosphate*
Inhibitor

\begin{tabular}{|c|}
\hline $\begin{array}{l}\text { None } \\
\text { None } \\
0.005 \text { M-Menthyl } \alpha \text {-glucuronide }\end{array}$ \\
\hline $\begin{array}{l}\text { None } \\
0 \cdot 0001 \text { m-Saccharo-1:4-lactone } \\
\text { None } \\
0 \cdot 01 \mathrm{M}-\mathrm{NaF} \\
0.0001 \mathrm{M}-\text { Saccharo-1:4-lactone }\end{array}$ \\
\hline $\begin{array}{l}\text { None } \\
0 \cdot 0001 \mathrm{~m}-\text { Saccharo-1:4-lactone } \\
\text { None } \\
0.01 \mathrm{M}-\mathrm{NaF} \\
\text { 0.0001 M-Saccharo-1:4-lactone }\end{array}$ \\
\hline
\end{tabular}

\section{None}

None

None

0.0001 M-Saccharo-1:4-lactone

0.0001 M-Saccharo-1:4-lactone

None

None

0.0001 M-Saccharo-1:4-lactone

$\begin{array}{cc}\begin{array}{c}\text { Glucuronic } \\ \text { acid liberated } \\ (\mu g .)\end{array} & \begin{array}{c}\text { Inhibition } \\ (\%)\end{array} \\ 69 & - \\ 0 & - \\ 67 & 3 \\ 129 & - \\ 8 & 94 \\ 27 & - \\ 20 & 26 \\ 26 & 4 \\ 113 & - \\ 4 & 96 \\ 37 & - \\ 27 & 27 \\ 6 & 84\end{array}$

* Concentration calculated on glucuronic acid content. 
saccharo-1:4-lactone, a powerful inhibitor for $\beta$ glucuronidase (Levvy, 1952). As shown in Table 3, the concentration of the lactone chosen caused almost complete inhibition of the hydrolysis of menthyl $\beta$-glucuronide. Inhibition of the hydrolysis of $\beta$-glucuronic acid-1-phosphate was also marked, and this compound must therefore be regarded as a substrate for $\beta$-glucuronidase. The lactone had no significant effect on the rate of hydrolysis of $\alpha$-glucuronic acid-1-phosphate. Hydrolysis in this case cannot therefore have been due to $\beta$-glucuronidase. The $\alpha$-phosphate must have acted as an enzyme inhibitor, in the ordinary sense of the word, in the experiments with phenolphthalein glucuronide (Table 1).

Hydrolysis of both glucuronic acid-1-phosphates was slightly inhibited by fluoride, which does not inhibit $\beta$-glucuronidase (Karunairatnam \& Levvy, 1949), suggesting that a phosphatase was present in the enzyme preparations.

Resynthesis of glucuronides. Storey (1950) has suggested that the synthesis of a glucuronide in the animal body may occur by condensation of the aglycone with glucuronic acid-1-phosphate (anomer unspecified) under the influence of a phosphorylase. It could also conceivably occur under the influence of $\beta$-glucuronidase, acting as a transferase. In the mouse, glucuronide synthesis occurs predominantly in the liver (Karunairatnam, Kerr \& Levvy, 1949). The possibility had to be considered that resynthesis of phenolphthalein glucuronide might have occurred in the experiments with the glucuronic acid-1phosphates shown in Table 1. The effects of the phosphates on the synthesis of $o$-aminophenyl glucuronide by mouse-liver preparations were therefore studied by the method of Levvy \& Storey (1949).

Mouse-liver homogenates were variously prepared in water, $0.9 \%(w / v)$ sodium chloride, $1.1 \%(w / v)$ potassium chloride and bicarbonate Ringer solution. In no instance did incubation of the homogenate with $\alpha$ - or $\beta$-glucuronic acid-1phosphate $(0.001$ and $0.005 \mathrm{M})$ and $o$-aminophenol $(0.0025 \%)$ in bicarbonate Ringer solution give detectable synthesis of $o$-aminophenyl glucuronide. Addition of $0.01 \mathrm{~m}$-sodium fluoride or $0.0002 \mathrm{M}$ saccharo-1:4-lactone, or both, to the incubation mixture did not lead to synthesis. In the synthesis of o-aminophenyl glucuronide by mouse-liver slices, addition of $\alpha$ - or $\beta$-glucuronic acid-1-phosphate $(0.001$ and $0.005 \mathrm{M})$ caused no stimulation, nor did these compounds overcome the inhibition produced by anaerobiosis (Storey, 1950).

\section{DISCUSSION}

The synthesis of laevomenthyl $\beta$-D-glucuronide, identical with the biosynthetic compound (Marsh, 1952), has afforded final proof that this compound and presumably other urinary glucuronides are $\beta$-D-glucopyranuronides. On the basis of the present work it would appear that mouse-liver glucuronidase is specific for this group of compounds, including $\beta$-D-glucopyranuronic acid-1phosphate. It is remarkable that methyl $\beta$-D. glucofuranuronide was neither a substrate nor an inhibitor for the enzyme, since saccharo-1:4-lactone with a similar ring structure is a powerful competitive inhibitor (Levvy, 1952).

Oxycellulose on a weight basis was about as effective as free glucuronic acid in slowing the hydrolysis of phenolphthalein glucuronide by the enzyme, but in the former case the effect was largely associated with dialysable material in the solution, which amounted to only $20 \%$ of the total solid. The net effect was too great to be accounted for in terms of free glucuronic acid present as impurity in the oxycellulose solution. It is considered likely that the action of oxycellulose was due to a mixture of oligosaccharides composed largely of $\beta$-linked glucuronic acid residues. Since oxycellulose is unstable to alkali it was found impossible to apply the measurement of reducing sugar, to decide whether any hydrolysis occurred in the presence of the enzyme.

Depression of the enzymic hydrolysis of phenolphthalein glucuronide by $\alpha$ - or $\beta$-glucuronic acid-1phosphate was open to a variety of explanations. The phosphate might have been an alternative substrate for the enzyme, or it might have been an enzyme inhibitor in the usual sense of the word. Hydrolysis, either spontaneous at the $\mathrm{pH}$ of enzyme assay, or under the action of some other enzyme than $\beta$-glucuronidase, might have yielded sufficient glucuronic acid to have caused marked inhibition. Lastly, resynthesis of phenolphthalein glucuronide might have occurred, in accordance with the theory of Storey (1950). Eventually it was found that $\beta$ glucuronic acid-1-phosphate was a substrate for $\beta$-glucuronidase and that the $\alpha$-anomer inhibited the enzyme, although both compounds were slowly hydrolysed at $\mathrm{pH} 5.2$ by a phosphatase in the glucuronidase preparations.

It should not be concluded that the experiments dealing with glucuronide synthesis disprove Storey's theory that glucuronic acid-1-phosphate is concerned in this process in the animal body. Some unknown factor may have been missing or deficient in the experiments with liver homogenates (Dutton \& Storey, 1951). In the experiments with liver slices, on the other hand, the glucuronic acid-1phosphates may not have penetrated the cell membrane. The results of our experiments do, however, make it very unlikely that any synthesis of phenolphthalein glucuronide from phenolphthalein can have occurred in the presence of $\beta$-glucuronidasepreparations and $\alpha$ - or $\beta$-glucuronic acid-1-phosphate. 


\section{SUMMARY}

1. On the basis of its action on a number of conjugated hexuronic acids and other compounds, it is concluded that mouse-liver glucuronidase is specific for $\beta$-D-glucopyranuronides, including $\beta$-D-glucopyranuronic acid-1-phosphate.

2. Derivatives of laevomenthol caused slight activation of glucuronidase.
3. Mouse-liver preparations did not catalyse the condensation of $o$-aminophenol with $\alpha$ - or $\beta$ glucuronic acid-1-phosphate.

The authors are indebted for various materials to the donors mentioned in the text, and to Dr P. G. Walker for assistance with many of the experiments on glucuronide synthesis.

\title{
REFERENCES
}

Barker, S. A., Bourne, E. J. \& Stacey, M. (1951). Chem. \& Ind. p. 970.

Dutton, G. J. \& Storey, I. D. E. (1951). Biochem. J. 48, xxix.

Fernandez-Garcia, R., Amoros, L., Blay, H., Santiago, E., Soltero-Diaz, H. \& Colon, A. A. (1950). El Crisol, Puerto Rico, 4, 40. Cited in Chem. Abstr. (1951), 45, 555.

Graham, A. F. (1946). Biochem. J. 40, 603.

Karunairatnam, M. C. (1950). Ph.D. Thesis, Edinburgh.

Karunairatnam, M. C., Kerr, L. M. H. \& Levvy, G. A. (1949). Biochem. J. 45, 496.

Karunairatnam, M. C. \& Levvy, G. A. (1949). Biochem. J. 44, 599.

Kerr, L. M. H., Campbell, J. G. \& Levvy, G. A. (1949). Biochem. J. 44, 487.

Kerr, L. M. H., Graham, A. F. \& Levvy, G. A. (1948). Biochem. J. 42, 191.
Levvy, G. A. (1946). Biochem. J. 40, 396.

Lovvy, G. A. (1952). Biochem. J. 52, 464.

Levvy, G. A. \& Storey, I. D. E. (1949). Biochem. J. 44, 295.

Marsh, C. A. (1952). J. chem. Soc. p. 1578.

Masamune, H. (1934). J. Biochem., Tokyo, 19, 353.

Mehltretter, C. L., Alexander, B. H., Mellies, R. L. \& Rist, C. F. (1951). J. Amer. chem. Soc. 78, 2424.

Meyer, K., Linker, A. \& Rapport, M. M. (1951). J. biol. Chem. 192, 275.

Smith, F. (1951). J. chem. Soc. p. 2646.

Storey, I. D. E. (1950). Biochem. J. 47, 212.

Talalay, P., Fishman, W. H. \& Huggins, C. (1946). J. biol. Chem. 166, 757.

Walker, P. G. \& Levvy, G. A. (1951). Biochem. J. 49, 620.

Yackel, E. C. \& Kenyon, W. O. (1942). J. Amer. chem. Soc. 64, 121.

\section{The Mechanism of the Action of Uricase}

\author{
BY RONALD BENTLEY* AND A. NEUBERGER \\ National Institute for Medical Research, Mill Hill, London, N.W. 7
}

(Received 23 May 1952)

The enzyme uricase was considered formerly to oxidize uric acid with quantitative formation of allantoin, carbon dioxide and hydrogen peroxide (Wiechowski, 1907; Batelli \& Stern, 1909; Keilin \& Hartree, 1936a; Holmberg, 1939; Davidson, 1942), as shown in the following equation:<smiles>COOC(=O)NCC(=O)NC(C)C(=O)O[Na]</smiles>

However, it was shown by Felix, Scheel \& Schuler (1929) that under some conditions oxygen uptake was more rapid than carbon dioxide production, and Schuler (1932) found that at $\mathrm{pH} 8.9$ the yield of carbon dioxide was only $17.8 \%$ of that expected from the oxygen consumption. These findings suggested that the first product of the

* Present address: Department of Biochemistry, Columbia University, College of Physicians and Surgeons, New York. enzymic oxidation was not allantoin, and the $\mathrm{pH}$ changes during oxidation indicated that the primary product was a substance of greater acid strength than uric acid. Indications of the structure of this first product were obtained in experiments in which uric acid was oxidized with permanganate. Fischer \&

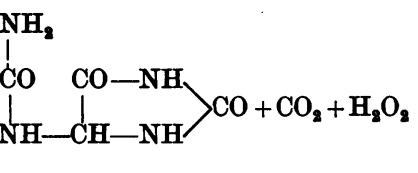

Ach (1899) had found that oxidation of 1-methyl and of 7-methyl-uric acid yields the same product, 3-methylallantoin, whilst 3-methyl- and 9-methyluric acid give 1-methylallantoin. Behrend (1904) pointed out that these findings can be explained by assuming that the first product of oxidation of uric acid by permanganate is a symmetrical compound, and he suggested that it possessed the structure $I$. This substance which Behrend was not able to isolate was named hydroxyacetylene diurein 